\title{
PROGRAM KAMPUNG IKLIM DI DESA CUPANG OLEH KEGIATAN CSR PT. INDOCEMENT Tbk.
}

\author{
Oleh: \\ Reza Rinaldy, Soni Akhmad Nulhaqim \& Arie Surya Gutama \\ Email: \\ rezarinaldy94@gmail.com; ariesurya_gutama@yahoo.com
}

\begin{abstract}
ABSTRAK
Pengembangan masyarakat adalah metode untuk dapat meningkatkan suatu kesejahteraan masyarakat, program pengembangan masyarakatpun banyak ditawarkan kepada masyarakat baik dari pemerintah maupun non pemerintahan. Perusahaan atau corpuration sebagai badan non pemerintahan yang berdasarkan UU No 40 Tahun 2007 berkewajiban melakukan tanggung jawab sosial khususnya yang bergerak di bidang sumber daya alam. Corpuration Social Responbility (CSR) sebagai bentuk kegiatan perusahaan dalam langkah untuk meningkatkan kesejahteraan masyarakat di lingkungan sekitarnya. Program CSR yang di maksudkan didalam UU tersebut mengarah kepada pembinaan masyarakat bukannya berbentuk sumbangan bantuan semata, perlunya tahapan yang benar dari perencanaan dan pelaksanaan adalah sebagai bagian dari langkah yang tepat untuk meningkatkan kesejahteraan masyarakat dan pandangan baik masyarakat terhadap perusahaan. Penelitian ini bertujuan untuk tahapan-tahapan proses program kampong iklim sebagai bentuk CSR di suatu perusahaan untuk dapat meningkatkan kesejahteraan masyarakatnya, dengan melihatan dari proses perencanaan sampai pelaksanaan. Subyek penelitian adalah pihak perusahaan sebagai perencana program dan masyarakat sebagai sasaran. Metode yang digunakan dalam penelitian ini adalah metode penelitian deskriptif dengan pendekatan kualitatif. Data primer dan sekunder diperoleh dari hasil penelaahan hasil studi kepustakaan.
\end{abstract}

\section{ABSTRACT}

The development of society is a method to improve the welfare of the community, many masyarakatpun development programs offered to the public both from government and nongovernment. Corpuration as a company or non-governmental entity under Law No. 40 of 2007 is obliged to social responsibility, especially those engaged in the field of natural resources. Corpuration Social Responsibility (CSR) as a form of corporate activities in a move to improve the welfare of the people in the surrounding neighborhood. CSR programs which are intended in the law leads to the development of society rather than the form of aid donations alone, the need for proper stages of planning and implementation as part of the appropriate measures to improve the welfare of society and the public good view of the company. This study aims to stages processes of climate kampong program as a form of CSR in a company to be able to improve the welfare of its people, with melihatan from the planning to implementation. Subjects were the company as a program planner and the community as a target. The method used in this research is descriptive method with qualitative approach. Primary and secondary data obtained from the review of the results of the study of literature. 


\section{PENDAHULUAN}

Perusahaan didirikan dengan tujuan untuk menghasilakan keuntungan sebesar-besarnya. Sebuah perusahaan adalah tindakan mendapatkan keuntungan semaksimal mungkin dan menekan kerugian seminimal mungkin. Perusahaan merupakan salah satu penopang dan penggerak perekonomian nasional. Peranan perusahaan dalam pertumbuhan ekonomi sangat baik. Penyedian lapangan kerja yang semakin besar, barang dan jasa yang dibuat dalam memenuhi kebutuhan manusia dan pembayaran pajak yang di bayarkan dalam membangun suatu bangsa dan negara. Sehingga banyak perusahaan baru bermunculan di daerah-daerah tidak hanya di perkotaan tetapi juga sudah memasuki kawasan daerah pedesaan seperti di daerah Cirebon yang diharapkan membawa pengaruh positif dalam peningkatan perekonomian.

Di sisi lain hadirnya perusahaan di berbagai daerah belakangan ini, membawa kabar yang tidak baik terkait dengan pengaruhnya terhadap lingkungan sekitar. Bahkan peningkatan perekonomian didaerah sekitar juga tidak membawa pengaruh yang cukup baik terhadap kesejahteraan masyarakat. Hal ini tentu sangat berkaitan dengan pola berpikir suatu perusahaan yang berlatar belakang ekonomi dengan profit (keuntungan) yang di kedepankan.

Dalam langkah menjaga hubungan baik dan mencegah terjadinya konflik antara masyarakat dan perusahaan. Oleh karena itu pemerintah memerintahkan setiap perusahaan selaku untuk melakukan tanggung jawab sosial atau CSR ( Corporate Social Responsibility). Untuk mewajibkan perusahaan dalam langkah mensejahterakan masyarakat terutama daerah sekitar, dengan berbagai program atau kegiatan yang di rencanakan oleh pihak perusahaan.

CSR adalah operasi bisnis yang berkomitmen tidak hanya untuk meningkatkan keuntungan perusahaan secara finansial, melainkan pula untuk pembangunan sosial- ekonomi kawasan secara holistik, melembaga dan berkelanjutan berdasarkan prosedur yang tepat dan profesional (Suharto,2008b)

Dalam meningkatkan pembangunan sosial ekonomi suatu masyarakat dalam disiplin pekerja sosial dapat menggunakan strategi pengembangan masyarakat (Comunity Development) dalam praktik pekerja sosial makro. Comdev dengan tujuan utama adalah memberdayakan individu-individu dan kelompok-kelompok orang melalui penguatan kapasitas (termasuk kesadara, pengetahuan, dan keterampilan-keterampilan) yang diperlukan untuk mengubah kualitas kehidupan komunitas mereka. (Suharto, 2007)

Perusahaan-perusahaan besar dan asosiasi-asosiasi industri mengembangkan program-program CSR bukan saja sebagai bagian dari "risk management" untuk merespon tekanan-tekanan konsumen dan masyarakat. Melainkan pula, menagkap pesan "good governance", mengembangkan peluang-peluang pasar, serta menerapkan pendekatan "bisnis etis" yang taat hukum, ramah lingkungan dan peduli sosial. Hal ini sejalan dengan tiga komponen penting sustainable development, yakni economic growth, environmental protection, dan social equilty, yang digagas the World Commission on Environmental and Development (WCED) (Brundtland Report:1987)

Dalam praktiknya program tanggung jawab sosial yang di lakukan oleh berbagai perusahaan masih banyak yang bersifat sukarela (Voluntary) dengan tidak ada tindakan yang suistanable (berkelanjutan). Kegiatan dan program yang di lakukan oleh perusahaan hanya bersifat amal dalam kegiatan yang cenderung hanya diadakan saja tanpa perencanaan yang matang. Sehingga dampak yang di berikan tidak meningkatkan kesejahteraan masyarakat kedepannya padahal perusahaan selaku stakeholder yang terlibat dalam meningkatkan kesejahteraan masyarakatnya seharusnya memberikan program tangung jawab sosial ini, secara 
berkelanjutan dalam hal menyelesaikan masalah-masalah sosial yang ada.

Dalam Undang-Undang Nomor 40 Tahun 2007 tentang Perseoran Terbatas yaitu pada Pasal 74 ayat (1) menyebutkan bahwa perseroan yang menjalankan usahanya di bidang dan/atau berkaitan dengan sumber daya alam wajib melaksanakan Tanggung Jawab Sosial dan Lingkungan.

Tujuan tanggung jawab sosial telah diatur di dalam pasal Pasal 1 butir 3 UndangUndang Nomor 40 Tahun 2007 tentang Perseroan Terbatas adalah untuk meningkatkan kualitas kehidupan dan lingkungan yang bermanfaat bagi perseroan itu sendiri, komunitas setempat dam masyrakat pada umumnya.

Pelaksanaan dari tanggung jawab sosial / CSR ini tentu tidak bersifat ekonomis atau menguntungkan tetapi apabila dilakukan dengan efektif, terencana dan strategis tentu dalam jangka panjang hal ini dapat membawa keuntungan bagi perusahaan yaitu sebuah investasi kedepannya yang akan menumbukan image (gambaran) baik terhadap suatu perusahaan yang mengakibatkan banyaknya kepercayaan yang di berikan kepada perusahaan kedepannya.

Seperti salah satu Perusahaan besar yang fokus terhadap bahan baku infrastruk pembangunan yaitu PT. Indocement Tbk Palimanan Kab. Cirebon. PT.Indocement sebagai salah satu perusahaan yang mengelola dan memanfaatkan sumber daya alam seperti material tanah yang ada didaerah tersebut. Sehingga PT.Indocement tentu harus melakukan tanggung jawab sosial / CSR kepada masyarakat sekitar.

Salah satu program tanggung jawab sosial dan lingkungan yang dilakukan adalah program kampung iklim di Desa Cupang Kec.Palimanan. Menarik program yang dilakukan oleh PT.Indocement karena program kampung iklim yang berfokus kepada lingkungan dan juga kesiapan masyarakat dalam menghadapi perubahaan iklim atau cuaca yang ada. Dalam hal ini peneliti tertarik akan pelaksanaan dari program kampung iklim, karena melibatkan masyarakat dalam berperan aktif untuk pelastarian lingkungan dan juga program kampung iklim pernah mendapatkan penghargaan, sehingga diharapkan informasi yang didapatkan dalam penelitian ini akan membawa pengaruh yang baik terhadap perencanaan-perencanaan dalam program-program tanggung jawab sosial dan lingkungan di perusahaan-perusahaan lainnya

\section{Metode Penulisan}

Metode yang digunakan dalam penulisan karya tulis ilmiah ini adalah metode penelitian deskriptif dengan pendekatan kualitatif. Metode yang digunakan untuk mengumpulkan data dari informan dengan pengambilan data secara perposif dan metode studi pustaka yang terdiri atas pencarian data dan informasi melalui dokumen-dokumen pendukung berupa data dari buku, jurnal ilmiah, dan dokumen elektronik dari internet. Adapun tahapan dalam penulisan diantaranya perumusan masalah untuk kemudian menjadi gagasan, pengumpulan data dan fakta terkait, Kerangka pemikiran

\section{TELAAH PUSTAKA}

\section{Corpuration Social Responbility}

Setiap perusahaan di seluruh dunia akan melakukan berbagai macam kegiatan yang terencana untuk dapat meningkatkan eksistensi perusahaan dan menjadi perusahaan yang Good Bussiness. Salah satu kegiatannya adalah Corporate Sosial Responsibility (CSR). CSR adalah kegiatan-kegiatan sosial yang dilakukan perusahaan sebagai bentuk tanggung jawab perusahaan terhadap masyarakat luas dan lingkungan. Usaha sosial perusahaan telah dikonsepkan lebih luas sebagai tugas manajerial untuk mengambil tindakan melindungi dan mengembangkan kesejahteraan masyarakat dan sekaligus memberikan keuntungan bagi perusahaan. Jadi kegiatan CSR pada dasarnya merupakan bentuk tanggung jawab perusahaan kepada 
masyarakat sekaligus sebagai sarana untuk membangun reputasi dan meningkatkan keunggulan perusahaan dalam bersaing.

CSR merupakan sebuah kesepakatan dari The World Bussiness Council for Sustainable Development (WBCSD) di Johannesburg Afrika Selatan pada tahun 2002 yang ditujukan untuk mendorong seluruh perusahaan dunia dalam rangka terciptanya suatu pembangunan berkelanjutan (sustainable development), bekerja dengan para karyawan perusahaan, keluarga karyawan, komunitas lokal dan komunitas secara keseluruhan dalam peningkatan kualitas hidup. Sanka dan Clement (2002) dalam Rudito dan Famiola (2007) mendefinisikan CSR sebagai komitmen usaha untuk bertindak etis, beroperasi legal dan berkontribusi untuk peningkatan ekonomi bersamaan dengan peningkatan kualitas hidup dari karyawan dan keluarganya, komuniti lokal dan masyarakat secara lebih luas.

Secara umum, CSR dapat didefinisikan sebagai bentuk kegiatan untuk meningkatkan kualitas hidup masyarakat melalui peningkatan kemampuan manusia sebagai individu untuk beradaptasi dengan keadaan sosial yang ada, menikmati, memanfaatkan dan memelihara lingkungan hidup yang ada.

Definisi CSR menurut berbagai organisasi ( Wikipedia 2008) :

- International Finance Corporation mendefinisikan CSR sebagai komitmen dunia bisnis untuk memberi kontribusi terhadap pembangunan ekonomi berkelanjutan melalui kerjasama dengan karyawan, keluarga mereka, komunitas lokal, dan masyarakat luas untuk meningkatkan kehidupan mereka melalui cara-cara yang baik bagi bisnis maupun pembangunan.

- Instituteof Chartered Accountant, England and Wales mendefinisikan CSR sebagai jaminan bahwa organisasi-organisasi pengelola bisnis mampu memberikan dampak positif bagimasyarakat dan lingkungan, seraya memaksimalkan nilai bagi para pemegang saham (shareholder) mereka.

- CSR menurut Canadian Government adalah sebuah kegiatan usaha yang mengintegrasikan ekonomi, lingkungan, dan sosial kedalam nilai, budaya, pengambilan keputusan, strategi, dan operasi perusahaan yang dilakukan secara transparan dan bertanggung jawab untuk menciptakan masyarakat yang sehat dan berkembang.

- Menurut European Commision, CSR merupakan sebuah konsep perusahaan yang mengintegrasikan perhatian terhadap sosial dan lingkungan dalam operasi bisnis mereka dan dalam interaksinya dengan para pemangku kepentingan (stakeholder) berdasarkan prinsip kesukarelaan.

- CSR Asia mendefinisikan CSR sebagai komitmen perusahaan untuk beroperasi secara berkelanjutan berdasarkan prinsip eknomi, sosial dan lingkungan, serta menyeimbangkan beragam kepentingan para stakeholder.

Selain itu, ISO 260000 mendefinisikan CSR sebagai tanggung jawab sebuah organisasi terhadap dampak-dampak dari keputusankeputusan dan kegiatan-kegiatannya pada masyarakat dan lingkungan yang diwujudkan dalam bentuk perilaku transparan dan etis yang sejalan dengan pembangunan berkelanjutan dan kesejahteraan masyarakat, mempertimbangkan harapan pemangku kepentingan, sejalan dengan hukum yang ditetapkan dan norma-norma perilaku internasional, serta terintegrasi dengan organisasi secara menyeluruh.

Wibisono (2007) mendefinisikan CSR sebagai tanggung jawab perusahaan kepada pemangku kepentingan untuk berlaku etis, meminimalkan dampak negatif dan memaksimalkan dampak positif yang mencakup aspek ekonomi dan sosial (triple bottom line) dalam rangka mencapai tujuan 
pembangunan berkelanjutan. Sementara Nursahid (2006) mendefinisikan CSR sebagai tanggung jawab moral suatu organisasi bisnis terhadap kelompok yang menjadi stakeholdernya yang terkena pengaruh baik secara langsung maupun tid Istilah CSR mulai digunakan sejak tahun 1970-an. Elkington (1998) mengembangkan tiga komponen penting sustainable development, yakni economic growth, environmental protection, dan social equity, yang digagas the World Commision on Environment and Development ( WCED ) dalam Brundtland Report (1987). Elkington mengemas CSR ke dalam tiga fokus, yaitu : 3P ( profit, planet, people). Perusahaan yang baik tidak hanya mencari keuntungan (profit) belaka, melainkan perusahaan harus memiliki kepedulian pula terhadap kelestarian lingkungan (planet) dan kesejahteraan masyarakat (people). Berdasarkan riset yang dilakukan oleh United States-based Business for Social Responsibility (BSR), banyak sekali keuntungan yang didapatkan oleh perusahaan yang telah mempraktekkan CSR antara lain:

1) Meningkatkan brand image dan reputasi perusahaan CSR dapat membuat perusahaan menjadi lebih dikenal oleh masyarakat sehingga reputasi perusahaan juga akan meningkat apabila perusahaan melaksanakan progaram tersebut dengan sebaik - baiknya.

2) Meningkatkan penjualan dan loyalitas pelanggan. Apabila program CSR dilakukan dengan baik oleh perusahaan maka para pelanggan akan menjadi lebih loyal karena para pelanggan tidak hanya mengetahui kualitas tetapi juga tujuan baik perusahaan.

3) Mengurangi biaya operasional. Dengan adanya CSR perusahaan tidak perlu lagi mengeluarkan anggaran untuk biaya promosi, karena produk atau perusahaan pasti akan menjadi lebih dikenal oleh masyarakat. Dengan demikian biaya operasional perusahaan akan menurun.

4) Meningkatkan kinerja keuangan.Dengan adanya CSR diharapkan laba perusahaan akan lebih meningkat karena penjualan juga akan meningkat. Dengan demikian kinerja keuangan dari perusahaan tersebut secara otomatis akan meningkat pula.

Program CSR, apabila dikembangkan dengan baik akan menciptakan suatu kaitan emosional antara masyarakat dengan perusahaan yang nantinya akan berdampak pada brand awareness, dan lama-kelamaan akan berkembang menjadi brand loyalty yang akan menciptakan ekuitas merek yang menguntungkan bagi perusahaan (Sen, 2005:37 dalam Anggraini, 2008).

Menurut Madura (2001:93) ada empat kemungkinan biaya yang timbul sebagai akibat tanggung jawab sosial yaitu :

1. Tanggung jawab kepada pelanggan

a) menciptakan program, menerima dan memecahkan keluhan.

b) melakukan survei untuk mengetahui kepuasan pelanggan.

c) Gugatan hukum oleh pelanggan.

2. Tanggung jawab kepada karyawan

a) menciptakan program menerima dan memecahkan masalah

b) melakukan survei untuk mengetahui kepuasan karyawan

c) gugatan hukum oleh karyawan karena diskriminasi atau tuduhan tanpa bukti

3. Tanggung jawab kepada pemegang saham

a) mengumumkan informasi keuangan secara periodik.

b) gugatan hukum oleh pemegang saham atas dasar tuduhan bahwa manajer perusahaan tidak memenuhi tanggung jawabnya kepada

c) para pemegang saham

4. Tanggung jawab kepada lingkungan

a) a. memenuhi regulasi pemerintah akan lingkungan

b) b. memenuhi janji akan petunjuk lingkungan yang dibuat perusahaan.

Wibisono (2007) menjelaskan bahwa penerapan CSR yang dilakukan mperusahaan dapat dibagi menjadi empat tahapan, yaitu 
tahap perencanaa, implementasi, evaluasi, dan pelaporan. Tanggung jawab sosial yang dilakukan oleh perusahaan di bagi menjadi 3 model, yaitu keterlibatan langsung, melalui yayasan atau organisasi sosial perusahaan, dan bermitra dengan pihak lain.

\section{Adapun bentuknya sebagai berikut :}

1. Grant (hibah) : bantuan dana tanpa ikatan yang di berikan oleh perusahaan untuk membangun investasi sosial.

2. Penghargaan (award) : pemberian bantuan oleh perusahaan kepada sasaran yang dianggap berjasa bagi masyarakat banyak dan lingkungan usahanya. Biasanya penghargaan dalam bentuk sertifikat dan sejumlah uang kepada perorangan atau institusi atau panti yang diselenggarakan secara berkelanjutan dan dalam waktu tertentu.

3. Dana Komunikasi Lokal (community Funds) : bantuan dana atau dalam bentuk lain bagi komunitas untuk meningkatkan kualitas di bidangnya secara berkesinambungan.

4. Bantuan Subsidi (social subsidies) : bantuan dana atau bentuk lainnya bagi sasaran yang berhak meningkatkan kinerja secara berkelanjutan seperti pemberian bantuan dana buruh lokal atau modal usaha kecil satu kawasan.

5. Bantuan pendanaan jaringan teknis bagi sasaran yang berhak untuk memperoleh pengetahuan dan ketrampilan sehingga mampu meningkatkan produktivitas. Misalnya, bantuan teknis untuk usaha kecil atau mikro.

6. Penyediaan pelayanan sosial seperti pendidikan, kesehatan, hukum, taman bermain, panti asuhan, beasiswa, dan berbagi pelayanan sosial lainnya bagi masyarakat.

7. Bantuan kredit usaha kecil dengan bunga rendah bagi rumah tangga, baik masyarakat yang tinggal di sekitar perusahaan maupun masyarakat pada umumnya.

8. Program bina lingkungan melalui pengembangan masyarakat.

9. Penyediaan kompensasi sosial bagi masyarakat yang menjadi korban polusi serta kerusakan lingkungan.

Implementasi program CSR merupakan realisasi dan aktualisasi dari upaya perusahaan untuk selalu dekat dengan masyarakat. Menurut Budimanta (dikutip oleh Mapisangka, 2009) CSR pada dasarnya merupakan suatu elemen yang penting dalam kerangka sustainability yang mencakup aspek ekonomi, lingkungan dan sosial budaya yang merupakan proses penting dalam pengelolaan biaya dan keuntungan bisnis dengan stakeholder baik secara internal maupun eksternal.

\section{Masyarakat Sebagai Sasaran Utama}

" Masyarakat" yang berarti pergaulan hidup kumpulan manusia yang hidup bersama dalam suatu tempat dengan ikatan aturan tertentu. Masyarakat menurut Hasan Sadily (1993) dalam Abied (2011) memberikan pengertian bahwa masyarakat adalah kesatuan yang selalu berubah, yang hidup karena proses masyarakat yang menyebabkan terjadi proses perubahan tersebut. Sedangkan menurut Plato, masyarakat merupakan refleksi dari manusia perorangan. Suatu masyarakat akan mengalami keguncangan sebagaimana halnya manusia perorangan yang terganggu keseimbangan jiwanya yang terdiri dari tiga unsur, yaitu nafsu, semangat, dan intelegensi.

Masyarakat adalah makhluk sosial. Manusia tidak dapat hidup sendiri dengan mengabaikan keterlibatannya dengan kepentingan pergaulan antara sesamanya dalam kehidupan bermasyarakat. Dalam hubungan manusia dengan masyarakat terjadi interaksi aktif. Manusia dapat mengintervensi dengan masyarakat lingkungannya dan sebaliknya masyarakat pun dapat memberi pada manusia sebagai warga. 
Kesejahteraan Masyarakat adalah salah satu pendekatan yang harus menjadi prinsip utama bagi seluruh unit-unit kepemerintahan maupun pihak korporasi dalam menjalankan tugas dan fungsinya dalam memberikan pelayanan sosial (Ambaddar, 2008 dalam Maulana, 2009). Kesejahteraan Masyarakat menurut Giarci (2001) dalam Subejo dan Supriyanto (2004) adalah suatu hal yang memiliki pusat perhatian dalam membantu masyarakat pada berbagai tingkatan umur untuk tumbuh dan berkembang melalui berbagai fasilitas dan dukungan agar mereka mampu memutuskan, merencanakan dan mengambil tindakan untuk mengelola dan mengembangkan lingkungan fisiknya serta kesejahteraan sosial.

Dalam lingkungan perusahaan, masyarakat di sekitar perusahaan merupakan pihak yang terpenting untuk memperoleh apresiasi. Apresiasi itu sendiri dapat berbentuk peningkatan kesejahteraan hidup melalui kegiatan pemberdayaan masyarakat yang dilakukan oleh perusahaan melalui kegiatan CSR.

Dalam penerapannya, umumnya perusahaan akan melibatkan partisipasi masyarakat, baik sebagai objek maupun sebagai subjek program CSR. Hal ini dikarenakan masyarakat adalah salah satu pihak yang cukup berpengaruh dalam menjaga eksistensi suatu perusahaan. Masyarakat adalah pihak yang paling merasakan dampak dari kegiatan produksi suatu perusahaan, baik itu dampak positif ataupun negatif. Dampak ini dapat terjadi dalam bidang sosial, ekonomi, politik maupun lingkungan ( Dalam penelitian Mapisangka, 2009 ).

Kesejahteraan masyarakat akan mendorong peningkatan daya beli, sehigga memperkuat daya serap pasar terhadap output perusahaan. Sedangkan kelestarian faktorfaktor produksi serta kelancaran proses produksi yang terjaga akan meningkatkan efisiensi proses produksi. Dua faktor tersebut akan meningkatkan potensi peningkatan laba perusahaan, dan dengan sendirinya meningkatkan kemampuan perusahaan mengalokasikan sebagian dari keuntungan untuk membiayai berbagai aktivitas CSR di tahun-tahun berikutnya ( Hertanto, 2008 ). Menurut Kim (2000) praktek CSR perusahaan dapat diidentifikasikan dalam berbagai tujuan, yakni hukum, ekonomi, moral dan filantropi. Namun demikian, tujuan tersebut masih dapat dikembangkan sesuai dengan kondisi aktual masyarakat terkait dengan tekanan yang terjadi dalam kehidupan masyarakat.

Menurut Oky Syaiful Harahap ( dalam Syahputra, 2008) masyarakat yang sejak awal berada di tingkat ekonomi yang rendah, merasa semakin terpuruk dengan kehadiran berbagai jenis perusahaan. Dengan melibatkan dan memberdayakan masyarakat sekitar dengan melakukan community development justru membuat jarak antara perusahaan dengan masyarakat. Jika ada program yang dilakukan perusahaan, biasanya dalam bentuk charity atau sumbangan sosial yang hanya bersifat sesaat dan berdampak sementara. Dengan konsep charity kapasitas dan akses masyarakat tidak berubah dari keadaan semula. Charity merupakan merupakan bagian kecil dari program CSR yang kurang tepat sasaran karena tidak dapat merubah keadaan ekonomi masyarakat sekitar perusahaan. Sehingga CSR diharapkan lebih mampu membantu menciptakan keseimbangan antara perusahaan, masyarakat, dan lingkungan.

Penelitian yang dilakukan Mapisangka (2009) bahwa perkembangan lingkungan perusahaan berjalan sedemikian cepat, sehingga membutuhkan berbagai inovasi dan kreasi kegiatan CSR yang mampu dirasakan masyarakat.

Salah satu elemen penting dalam kesejahteraan hidup tersebut adalah adanya kegiatan pemberdayaan masyarakat sekitar perusahaan. Dalam hal ini peran manajemen perusahaan sangat penting dalam upaya untuk memformulasikan berbagai kegiatan CSR perusahaan, sehingga terjadi hubungan simbiosis mutualisme antara perusahaan dan masyarakat luas. Pada akhirnya kegiatan CSR perusahaan diharapkan dapat meningkatkan pemberdayaan masyarakat. 


\section{PENGEMBANGAN MASYARAKAT}

Community Development Program (Program Pemberdayaan Masyarakat) merupakan suatu progam / proyek yang bertujuan untuk mempercepat penanggulangan kemiskinan berdasarkan pengembangan kemandirian masyarakat melalui peningkatan kapasitas masyarakat, Partisipasi masyarakat dan kelembagaan dalam penyelenggaraan pembangunan.

Terpuruknya perekonomian negara ditambah semakin merajalelanya korupsi, kolusi, dan nepotisme secara langsung membuat masyarakat menjadi tidak berdaya. Masyarakat yang hidup di bawah garis kemiskinan semakin meningkat, pengangguran yang sudah mencapai 40 juta, keluarga jalanan dan anak jalanan menjadi masalah sosial yang menonjol di perkotaan; anak-anak putus sekolah pada semua jenjang pendidikan makin bertambah, masalah kriminalitas yang makin meningkat, ditambah dengan masalah sosial lainnya yang membuat masyarakat tidak berdaya memenuhi kebutuhan pokoknya

Pola pemberdayaan masyarakat bukan merupakan kegiatan yang sifatnya top-down intervention yang tidak menjunjung tinggi aspirasi dan potensi masyarakat untuk melakukan kegiatan swadaya, karena yang paling dibutuhkan masyarakat lapisan bawah terutama yang tinggal di desa adalah pola pemberdayaan yang sifatnya bottom-up intervention yang menghargai dan mengakui bahwa masyarakat lapisan bawah memiliki potensi untuk memenuhi kebutuhannya, memecahkan permasalahannya, serta mampu melakukan usaha-usaha produktif dengan prinsip swadaya dan kebersamaan

Konsep Community Development telah banyak dirumuskan di dalam berbagai definisi. Perserikatan Bangsa-Bangsa mendefinisikannya: " as the process by which the efforts of the people themselves are united with those of governmental authorities to improve the economic, social and cultural conditions of communities, to integrade these communities into the life of the nations, and to enable them to contribute fully to national progress". (Luz. A. Einsiedel 1968:7).

Definisi di atas menekankan bahwa pembangunan masyarakat, merupakan suatu "proses" dimana usaha-usaha atau potensipotensi yang dimiliki masyarakat diintegrasikan dengan sumber daya yang dimiliki pemerintah, untuk memperbaiki kondisi ekonomi, sosial, dan kebudayaan, dan mengintegrasikan masyarakat di dalam konteks kehidupan berbangsa, serta memberdayakan mereka agar mampu memberikan kontribusi secara penuh untuk mencapai kemajuan pada level nasional.

US International Cooperation Administration mendeskripsikan Community Development itu sebagai : " a process of social action in which the people of a community organized themselves for planning action; define their common and individual needs and problems; make group and individual plans with a maximum of reliance upon community resources; and supplement the resources when necessary with service and material from government and non-government agencies outside the community ". ( The Community Development Guidlines of the International Cooperation Administration, Community Development Review, December,1996,p.3).

Definisi di atas lebih menekankan bahwa konsep pembangunan masyarakat, merupakan suatu proses "aksi sosial" dimana masyarakat mengorganiser diri mereka dalam merencanakan yang akan dikerjakan; merumuskan masalah dan kebutuhankebutuhan baik yang sifatnya untuk kepentingan individu maupun yang sifatnya untuk kepentingan bersama; membuat rencana-rencana tersebut didasarkan atas kepercayaan yang tinggi terhadap sumbersumber yang dimiliki masyarakat, dan bilamana perlu dapat melengkapi dengan bantuan teknis dan material dari pemerintah dan badan-badan nonpemerintah di luar masyarakat. 
Melengkapi kedua definisi di atas, Arthur Dunham seorang pakar Community Development merumuskan definisi Community Development itu sebagai berikut. "organized efforts to improve the conditions of community life, and the capacity for community integration and self-direction. Community Development seeks to work primarily through the enlistment and organization of self-help and cooprative efforts on the part of the residents of the community, but usually with technical assistance from government or voluntary organization.(Arthur Dunham 1958: 3)

Rumusan di atas menekankan bahwa pembangunan masyarakat merupakan usahausaha yang terorganisasi yang bertujuan untuk memperbaiki kondisi kehidupan masyarakat, dan memberdayakan masyarakat untuk mampu bersatu dan mengarahkan diri sendiri. Pembangunan masyarakat bekerja terutama melalui peningkatan dari organisasi-organisasi swadaya dan usaha-usaha bersama dari individu-individu di dalam masyarakat, akan tetapi biasanya dengan bantuan teknis baik dari pemerintah maupun organisasi-organisasi sukarela.

Arthur Dunham membedakan "Community Development" dengan "Community Organization" : community development is concerned with economic life, roads, buildings, and education, as well as health and welfare, in the narrower sense. On the other hand, community welfare organization is concerned with adjustment of social welfare needs and resources in cities, states, and nations as in rural villages.

Jadi community development lebih berkonotasi dengan pembangunan masyarakat desa sedangkan community organization identik dengan pembangunan masyarakat kota.

Lebih lanjut Dunham mengemukakan 4 unsurunsur Community development sebagai berikut. 1. a plan program with a focus on the total needs of the village community; 2.technical assistance; 3 . integrating various specialities for the help of the community; and
4. a major emphasis upon selp-help and participation by the residents of the community

\section{PENDEKATAN CSR}

\section{Corporate Social Responsibility Goal}

Implementasi CSR dilakukan sedemikian rupa secara sistematis, terstruktur dan periodik. Tujuan CSR senantiasa mengedepankan persoalanpersoalan vital yang dihadapi masyarakat dalam peningkatan kesejahteraannya, antara lain bidang agama, ekonomi, pendidikan dan kesehatan. Tujuan tersebut dapat dilaksanakan berdasarkan visi dan misi perusahaan. Berdasarkan tujuantujuan CSR tersebut, implementasi CSR perusahaan akan mengikuti arah dari kepentingan perusahaan di tengah-tengah komunitas lingkungan hidup masyarakat.

Tujuan-tujuan CSR tersebut seperti tujuan dalam kerangka tanggung jawab pendidikan, ekonomi, moral, filantropi (kedermawanan) dan tujuan dalam tanggung jawab hukum.

\section{Corporate Social Issue}

Isu-isu sosial akan terus berkembang seiring dengan dinamika yang terjadi dalam kehidupan sosial kemasyarakatan. Isu-isu sosial tersebut berkembang sebagai wujud dari adanya perubahan dalam cara pandang hidup masyarakat yang harus segera direspon oleh perusahaan. Ketidakmampuan perusahaan dalam menangkap isu sosial yang berkembang di masyarakat akan berdampak pada bentrokan yang terjadi di tengah-tengah komunitas kehidupan sosial masyarakat.

Apalagi dalam suasana krisis ekonomi dunia yang sedang terjadi, persoalan perburuhan, komunikasi pemerintah dan perusahaan, bahkan hubungan pekerja di dalam perusahaan sendiri akan dapat terganggu dari mencuatnya isu sosial dalam masyarakat. Dalam hal ini menurut Giddens ( dalam Mapisangka 2009) dampak dari globalisasi yang terjadi tidak hanya mempunyai dimensi ekonomi saja akan tetapi juga mempunyai dimensi politik, 
teknologi, dan budaya. Pemikiran tersebut juga akan mempengaruhi cara berpikir kalangan usahawan dalam memandang strategi usahanya. Perusahaan tidak lagi dipandang sebagai bagian luar dari masyarakat tetapi perusahaan sudah merupakan bagian dari masyarakat.

\section{Corporate Relation Program}

Implementasi program CSR merupakan realisasi dan aktualisasi dari upaya perusahaan untuk selalu dekat dengan masyarakat. Menurut Budimanta (dikutip oleh Mapisangka, 2009) CSR pada dasarnya merupakan suatu elemen yang penting dalam kerangka sustainability yang mencakup aspek ekonomi, lingkungan dan sosial budaya yang merupakan proses penting dalam pengelolaan biaya dan keuntungan bisnis dengan stakeholder baik secara internal maupun eksternal.

\section{IMPLEMENTASI CSR TERHADAP KESEJAHTERAAN MASYARAKAT}

Implementasi CSR yang dilakukan oleh suatu perusahaan akan berdampak bagi perusahaan itu sendiri dan masyarakat di sekitar perusahaan. Dampak bagi perusahaan adalah peningkatan citra perusahaan di mata masyarakat dan meningkatkan hubungan baik dengan masyarakat dengan memberikan pengaruh sosial dilingkungan masyarakat dengan memberikan beberapa perubahan sosial didalamnya. Sedangkan dampak bagi masyarakat sekitar perusahaan adalah peningkatan kesejahteraan hidup masyarakat. Berdasarkan teori citra yang mengatakan bahwa sebuah perusahaan dalam menjalin hubungan dengan masyarakat harus mencipatkan komunikasi yang positif sehingga akan menciptakan kepercayaan terhadap perusahaan. Dalam lingkup pembentukan citra suatu perusahaan dalam kaitannya dengan program CSR yang memberikan pengaruh perubahan sosial pada masyarakat. Hal ini juga di pengaruhi oleh teori legitimasi, teori ini menjelaskan bahwa perusahaan melakukan kegiatan usaha dengan batasan-batasan yang ditentukan. Keberadaan perusahaan dalam masyarakat akan tetap berlanjut jika tindakan perusahaan sejalan dengan nilai-nilai masyarakat dimana perusahaan beroperasi pengimplimentasiaan program CSR sebagai pembentukan citra perusahan di mata masyarakat dan menciptakan hubungan positif untuk dapat terus beroperasinya suatu perusahaan dan memberikan dampak baik bagi perusahaan. Kedua teori tersebut dapat dijadikan landasan perusahaan dalam melaksanakan CSR dengan melihat tujuan, masalah, serta program CSR demi kesejahteraan masyarakat serta kelangsungan bisnis perusahaan.

Implementasi program CSR merupakan realisasi dan aktualisasi dari upaya perusahaan untuk terus dekat dengan perusahaan. Menurut Budimanta et al. (2008:24) dalam Mapisangka, 2009 bahwa CSR pada dasarnya merupakan suatu elemen yang penting dalam kerangka sustainability yang mencakup aspek ekonomi, lingkungan dan sosial budaya yang merupakan proses penting dalam pengelolaan biaya dan keuntungan kegiatan bisnis dengan stakeholders baik secara internal ( pekerja, shareholder, dan penanaman modal), maupun eksternal (kelembagaan, pengaturan umum, anggota-anggota masyarakat, kelompok masyarakat sipil dan perusahaan lain ). Program CSR yang berlangsung secara rutin dan terjadwal diharapkan dapat memberikan respon positif dan perusahaan memperoleh pengakuan bahwa perusahaan memiliki nilai sosial yang berkontribusi positif bagi masayarakat.

Pengimplementasian CSR dengan menggunakan metode Pengembangan Masyarakat (CO/CD) untuk memberdayakan masyarakat. Pemberdayaan adalah serangkaian kegiatan untuk memperkuat kekuasaan atau keberdayaan kelompok lemah dalam masyarakat, termasuk individu-individu yang mengalami masalah kemiskinan. Sebagai tujuan, maka pemberdayaan menunjuk pada keadaan atau hasil yang ingin dicapai oleh sebuah perubahaan sosial; yaitu masyarakat 
yang berdaya, memiliki kekuasaan atau mempunyai pengetahuan dan kemampuan dalam memenuhi kebutuhan hidupnya baik yang bersifat fisik, ekonomi, maupun sosial.

Dalam upaya agar CSR mampu memberdayakan masyarakat, maka perlu diketahui elemen-elemen keberdayaan. Semakin banyak elemen yang dimiliki sebuah masyarakat atau organisasi tersebut semakin kuat dan memiliki kapasitas, karena semakin berdayalah suatu masyarakat (Phip Bartle, 2008)

\section{Altruisme}

2.Nilai-nilai bersama

3.Pelayanan bersama

4.Kepercayaan diri

5.Jaringan

6.Keterampilan

7.Organisasi

8.Persatuan da

9.Kemakmuran

\section{PENUTUP}

Pengimplementasian program kampung iklim CSR dapat diukur keberhasilannya yaitu (Leimona dan Fauzi 7989 :2008) :

1. Kepemimpinan, dimana kepedulian dan komitmen pemimpin tertinggi perusahaan sebagai kebijakan utama.
2. Kebijakan, dengan dituangkannya kebijakan CSR berdimensi lingkungan secara tertulis sebagai keseriusan perusahaan dalam menjaga kelestarian lingkungan lewat program CSR.

3. Pengembangan program, Usulan program yang bersumber dari ide atau keinginan perusahaan atau pemerintah/masyarakat bahkan kombinasi keduanya.

4. Instalasi Sistem, Internalisasi program CSR berdimensi lingkungan kedalam operasi perusahaan merupakan kecenderungan strategi yang diterapkan banyak perusahaan di Indonesia.

5. Pengukuran dan Pelaporan, mengukur kinerja dan melaporkan hasilnya.

\section{DAFTAR PUSTAKA}

Edi Suharto.CSR \& COMDEV Investasi Kreatif Perusahaan di ERa Globalisasi.Alfabeta.2010.Bandung.

Hendrik Budi Untung.Corporate Social Responbility.Sinar

Grafika.2008.Jakarta.

Irawan Soehartono. Metode Penelitian Sosial. Remaja Rosdakarya.2011.Bandung.

Isbandi Rukminto Adi. Ilmu Kesejahteraan Sosial dan Pekerja Sosial. FISIP UI Press.2005.Jakarta.

SKRIPSI UNDIP "Pengaruh Implementasi CSR Terhadap Kesejahteraan Masyarakat”. Di lihat pada tanggal 12 April 2015. 